\title{
Using GIS to Improve Accuracy and Efficiency in Election Administration
}

\author{
Kim Brace
}

Abstract In addition to managing voter registration and voting, election administrators in many local jurisdictions are responsible for dividing voters into precincts. This process requires election administrators to often use data from the Census and sophisticated Geographic Information Systems software for mapping. The process of redistricting presents a variety of challenges ranging from the technical use of the software to considering the different political boundaries that voters must be incorporated into. Discussed are the challenges of redistricting and a potential strategy to address the challenges and limitations.

Keywords Redistricting $\bullet$ Precincting $\bullet$ Geographic Information Systems (GIS) • Street files • Boundaries

My work in the election administration field began decades back, when I was the late Dick Smolka's student at American University, and he helped me focus on county and local election officials and why they do what they do. Dick is perhaps best known by younger election officials for his

K. Brace $(\bowtie)$

Election Data Services, Inc., Manassas, VA, USA

(C) The Author(s) 2019

M. Brown et al. (eds.), The Future of Election Administration, Elections, Voting, Technology, https://doi.org/10.1007/978-3-030-18541-1_25 
founding and operation of Election Administration Reports, the first and still key newsletter for the field. I was his associate editor for a time. Then, and later through my work as a journalist, I started to understand the differences between localities in election practices, where people are coming from, and how to interpret in common terms what local election officials are doing. How to interpret information in common (ordinary) terms was particularly important. And as a journalist, helping people to understand what is happening through a story is also important.

Pictures are a particularly powerful way to tell stories, or parts of stories. In the "old days" we had paper maps of political jurisdictions, state and Congressional districts, and precincts. Now we have more modern tools. Geographic Information Systems (GIS) is the newest tool that we can use to do this - to tell a story. GIS is computer based, and so helping election officials understand that GIS is not scary, but simply a modern, and more efficient, tool is an important part of what I do.

\section{The Simplicity of Using GIS for "Precincting"}

In talking with election officials about precincting, I start with the concepts of points, lines, and polygons. This is what election officials deal with all the time in the process of precincting, which is assigning voters' home addresses (the points) through their street (the lines) and how it relates to a particular precinct (the polygon). Once they understand these basic building blocks, they can see how GIS can be of use to them. They also see how to use this tool to help them as we move toward an era in which we are engaging in more frequent redistricting; they can be prepared for the changes about to take place.

This approach to precincting includes many different components and stakeholders. To accomplish it, we combine information from the US Census and other available resources. We usually include data from the county auditor or other entity which keeps track of the location and dimensions of land parcels (with their address, of course). This provides election officials with a ready data set that they can use as a resource. Today the Census has a wealth of data including geographic land features as well as political lines and man-made infrastructure such as roads; now we can overlay all of these on top of aerial photographs, so election officials can see these data together with GIS to help them more quickly and accurately define precincts.

Election officials can use GIS to identify and map "points" such as addresses, where people live, street intersections, and particular locations 
such as polling sites. Election officials can also see "lines" such as streets, rivers, and railroads, and invisible lines such as county or city boundaries. They can count up voters (points) who live within line boundaries drawn as "polygons," like their precincts. When their legislature says, "Here is our new redistricting bill," the election official can take the different pieces of information and more easily see where the new districts lie. Shapefiles from the state government of new districts that contain this information make reprecincting much easier if election officials have access to GIS and know how to use it. If they have their registered voters properly "geocoded" (placed as a point on the map), they can easily see where precincts have been split by the new districts and the sizes of each piece. The GIS system can then help them redraw their precincts and constantly report back how many registered voters are affected in and by the new precinct(s), thereby allowing them to stay within their state's election law limits on the size of precincts. The GIS and aerial photographs can assist them in determining where best to place their polling place also. Figures 25.1, 25.2,

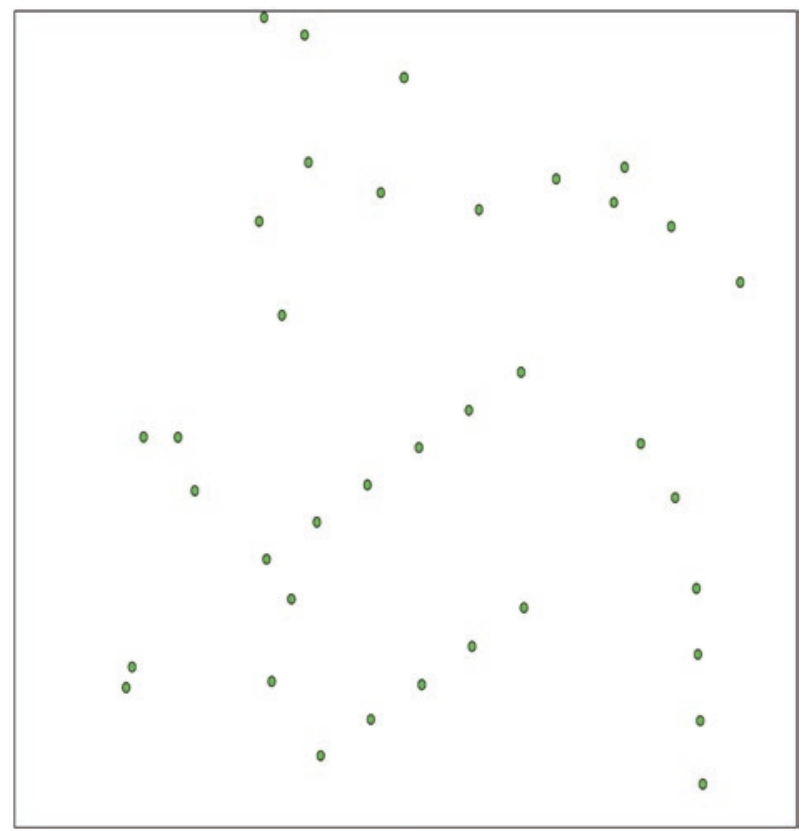

Fig. 25.1 GIS points as addresses, voters, intersections, polling places 


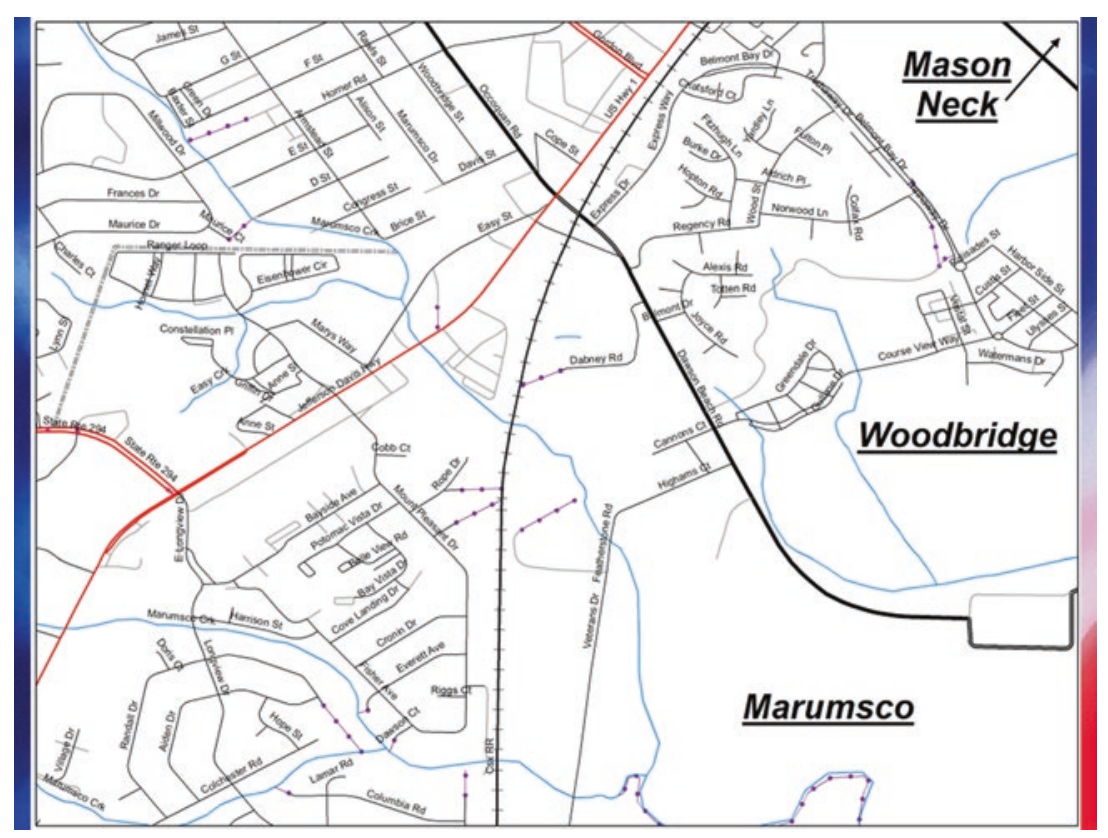

Fig. 25.2 GIS lines as streets, rivers, railroads, and invisible boundaries

25.3, and 25.4 illustrate these various GIS layers and how they all come together.

It is this overlay of a multitude of different districts (Congressional, State Senate, State House, local districts, taxing districts) that creates problems for election officials. This interaction creates different ballot styles, which increases the cost of conducting elections (more different ballots have to be printed) as well as leads to voter confusion for those who don't understand these different layers.

\section{Practical Limitations}

Many times the people at the state level who do redistricting do not reach down to local election officials for information; however, they should. One of the things I try to encourage local officials to do is to testify to state legislative bodies to remind them of (and identify for them) the impact of legislative decisions in terms of precincts and how voters interact with the elections process. Election officials can spot decisions that are 


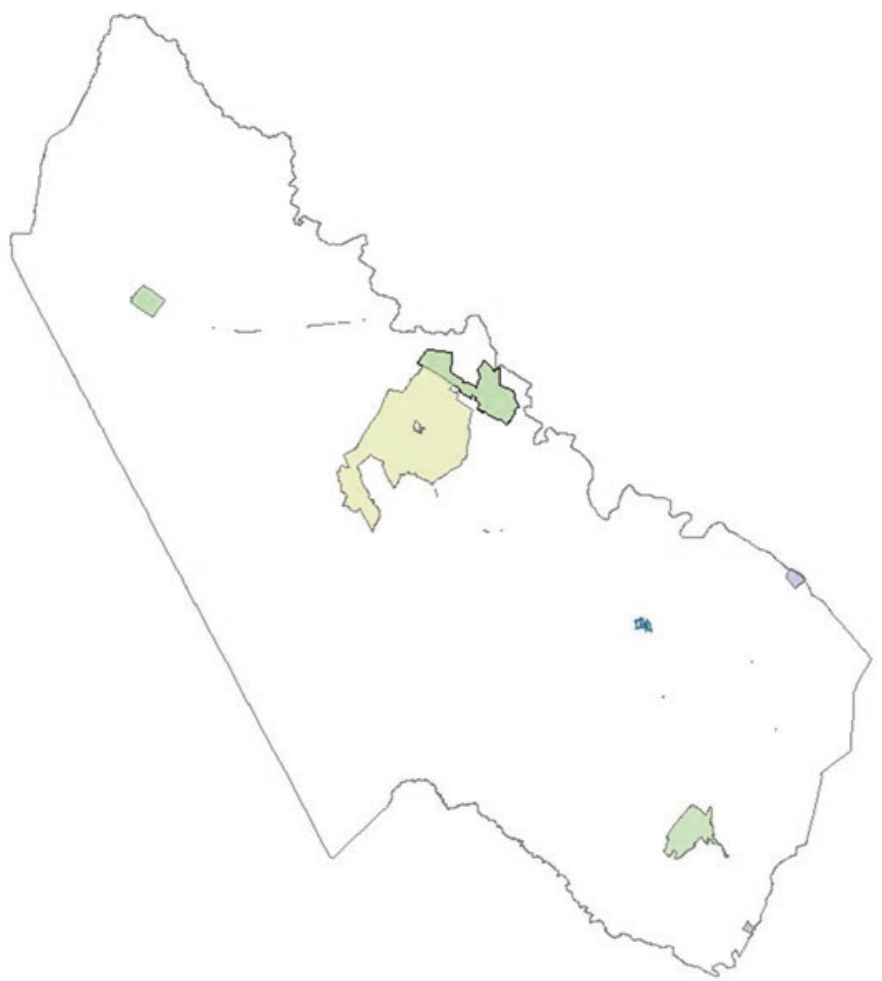

Fig. 25.3 GIS polygons as parcels, precincts, districts, city boundaries

made at the state level that will cause voter confusion, and thus also cause problems for local officials.

I also encourage legislators to review the various district boundaries they create with an eye on what happens when they overlay their plans on top of each other. Because state representatives tend to draw their own chamber's districts (State House members draw the State House Districts, while State Senators draw the State Senate Districts) they seldom look to see how one chamber's districts might impact the other chamber's plan. Failure to do so will lead to small pockets of people who have their own unique ballot style, even when there is just a handful of voters in that circumstance. Taking an extra day to check plans against each other can 


\section{Prince William County, VA}

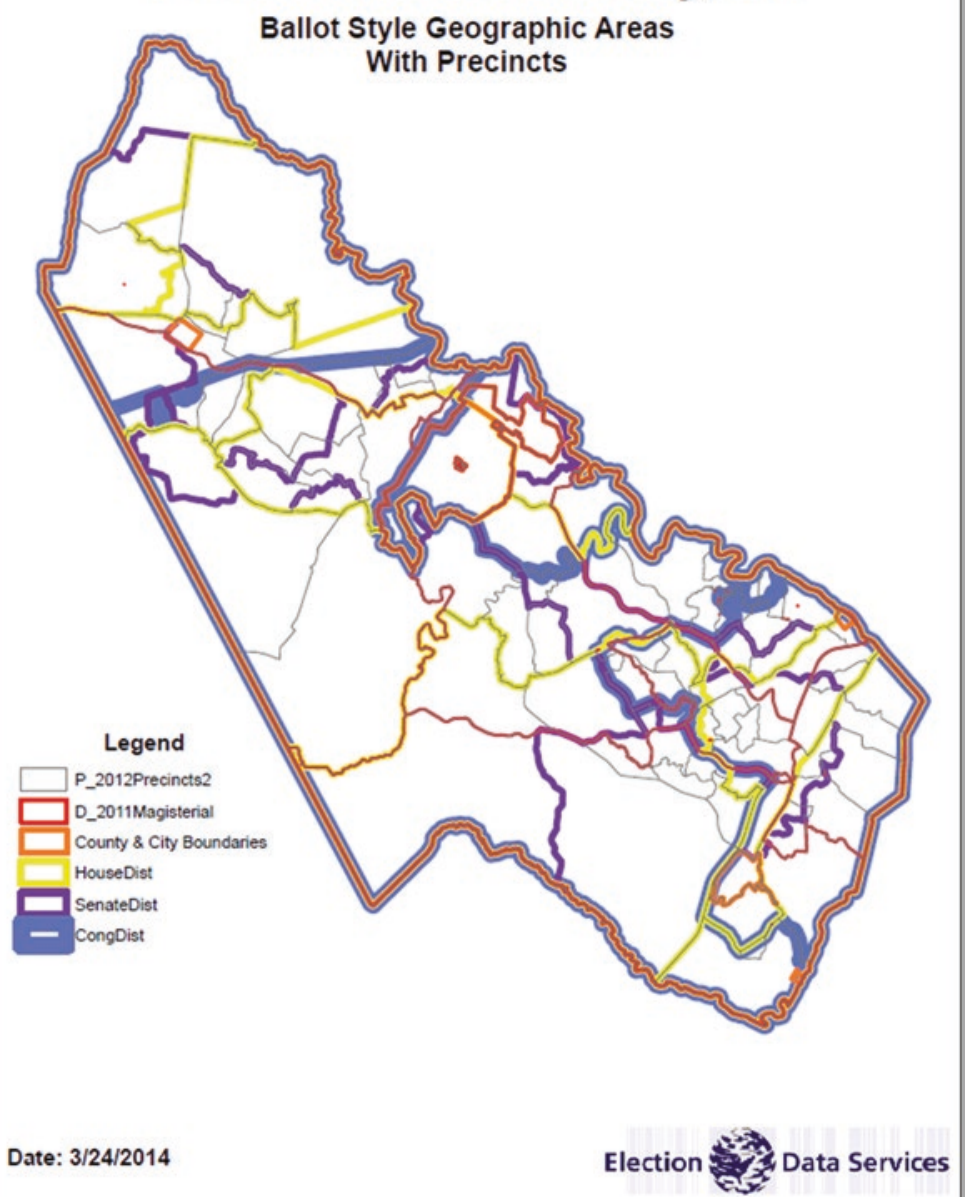

Fig. 25.4 GIS map illustration with multiple layer effect

greatly eliminate the headaches experienced by election administrators, who have to deal with all the variations possibly seen for the first time.

Legislatures draw district lines in ways that, generally, distribute population. But they don't take into account the details of the voter registration systems that local election officials use to manage voters and their precinct lines, and this creates confusion for local election officials when they try to 
implement the new district changes. The heart of most voter registration systems is a file called the "Street File." This is a listing of all streets in the jurisdiction, many of which are broken apart at a particular address number when the precinct, district, city, or special taxing district changes. In addition, the street file may contain an indication of whether the precincts, districts, and so on, apply to either the "even" or the "odd" side of the street (when the boundary line goes down the middle of the street) or "both" (when the street is encompassed by an area). These street files can run thousands or tens of thousands of records, depending on the size of the jurisdiction. When redistricting occurs these street records need to be either reassigned and possibly reconstructed to a new district area or bifurcated with new address range breaks.

It's not as though the various legislative bodies all use "Main Avenue" or some other obvious thoroughfare in a straightforward way. Instead, when the various boundary lines are laid on top of each other, one ends up creating "sawtooths" or district lines that are jagged and that run back and forth across a street. The voter registration system's "street files" are immensely complicated to break apart and reconstruct to accommodate newly mandated sawtooth borders; ultimately, this can result in errors and potentially confusion for voters.

Another cause of significant voter assignment error deals with cul-desacs. A cul-de-sac is a single record entry in that 10,000-record street file. Election officials know they need to check and adjust the multiple records for "Main Street" or other streets with address breaks. But they miss that single record for the cul-de-sac and those voters tend to retain their old precinct assignment (maybe needing to go 5 miles to the polling place), despite the fact that all other voters in the area have been reassigned to the school two blocks away. The voters in the cul-de-sac probably talk with each other and they all know they need to vote the next day 5 miles away. If they would only talk with their neighbors over their back fence, they would discover that polling place two blocks away.

\section{GIS and Relationship Building as a SOLution}

This entire process can be made much easier if GIS is used. The first step is to "geocode" the voter registration records and then compare their existing precinct assignment information (retained in the voter record) against the precinct number in that new precinct polygon. Where this information is different there is an error someplace and it needs to be investigated. 
We have to increase the capacity of local election offices to use GIS to solve these problems. Because building permits and new street creation are typically initiated and maintained at the local level, it is usually better that research start at the local level than at the state level. Local officials have a better understanding of where new construction is taking place in their town, which means they have better information than state officials will. But, unfortunately, the resources to use GIS for redistricting and precincting at the local level are thin, and election officials are not necessarily trained to do this.

In addition to providing local offices with better tools, we need to encourage local election officials to rethink their basic approach. Local election officials are often focused on recreating or readjusting the street file records within the election office, but better information is often housed in another local office. One part of the solution is fairly straightforward. The local tax assessor is certainly aware of what is going on with new construction because new developments are revenue sources; they could be a valuable resource. Election officials, however, tend to recreate this wheel. They shouldn't. They need to talk to other county officialssuch as the tax assessor-to identify the information that is already available to help with the precincting process.

\section{BARriers TO SUCCESS}

\section{Politics}

Registrars and other election officials who engage in precincting must keep their focus on the technical parts of their work. They must also stay away from the political fights involved in this process. Election officials should be hesitant to get involved in political fights, but they should get involved in legislative practice that influences their work. There is a difference between appointed and elected officials in this process. The elected officials have a political hat on, but they need to remember they are elected for a particular county and by the people in that county.

\section{Advanced Planning}

Another barrier for election officials is not getting out in front of precincting when redistricting is happening and being prepared for the results. Election officials know the neighborhoods in their counties. The legisla- 
tors from those counties know them too, and the legislators need to be reminded about how those voters will understand the results of the process and the results of different options. Election officials should remind legislators about which things to be cognizant of as they draw districts. This can be done regardless of whether an election official is elected or appointed.

\section{Small Districts at County Lines}

Legislators also need to be reminded not to "go into" other counties to capture a small group of people. Local election officials have to deal with this by creating tiny unique ballot areas. These tiny districts mean that different ballots and ballot styles have to be prepared for a small number of voters. This translates into a waste of county and state money as well as local resources. Legislatures need to build in additional time for local officials to overlay these maps to look for those small pockets and figure out how to eliminate them, because these pockets cause problems for local election officials and cost money.

\section{Preparing Boundary Changes}

New and better technology also means that election officials and other county or local officials need to be prepared to rethink existing politicalgeographic lines. For example, New England comprises many small townships. As the technical accuracy of Census files have been improved, we have cases in which the national understanding of the town boundaries is different than what local officials believe to be the case. When the Census drew their original township lines in the 1970s, the technology and ability to observe and record granular details was significantly less sophisticated than it is today. As technology has improved and our subsequent understanding of where these boundaries are has changed, discrepancies arise and the process of fixing these discrepancies is ongoing. The process has implications for election officials and for voters as well who need to be able to understand the results of these decisions and act on them. 
Open Access This chapter is licensed under the terms of the Creative Commons Attribution 4.0 International License (http://creativecommons.org/licenses/ by $/ 4.0 /$ ), which permits use, sharing, adaptation, distribution and reproduction in any medium or format, as long as you give appropriate credit to the original author(s) and the source, provide a link to the Creative Commons licence and indicate if changes were made.

The images or other third party material in this chapter are included in the chapter's Creative Commons licence, unless indicated otherwise in a credit line to the material. If material is not included in the chapter's Creative Commons licence and your intended use is not permitted by statutory regulation or exceeds the permitted use, you will need to obtain permission directly from the copyright holder. 